\title{
Chapter 8 \\ Looking for the (Fictitious) Employer - Umbrella Companies: The Swedish Example
}

\author{
Annamaria Westregård
}

\section{Introduction}

A new business model - a version of the umbrella company, or egenanställningsföretag as they are called in Swedish - has been adopted in Sweden. ${ }^{1}$ It is not a new phenomenon - it was first seen in Sweden during the $1990 s^{2}-$ but it was not until the collaborative economy developed that the industry grew, as the business model suits the digitalised world well. ${ }^{3}$ In the collaborative economy some platforms assign umbrella companies as middlemen to handle the transactions between the umbrella company worker and the client (service consumer). ${ }^{4}$ The parties rarely meet in real life: all contacts

1 Eurofound, New Forms of Employment, Publications Office of the European Union, Luxembourg, 2015, pp. $118 \mathrm{ff} .$, https://www.eurofound.europa.eu/sites/defa ult/files/ef_publication/field_ef_document/ef1461en.pdf. Accessed 12 September 2020, those companies are called umbrella companies. See also Government White Paper SOU 2017:24, Ett arbetsliv i förändring - hur påverkas ansvaret för arbetsmiljön?, pp. $159 \mathrm{ff}$.

2 For more on the historical development of umbrella companies in Sweden see Government White Paper SOU 2017:24 (fn. 1), pp. 159 ff.

3 It is difficult to determine how widespread the business model is and how many umbrella company workers there currently are. According to the branch organisation, the number of umbrella company employees grew from 4,000 in 2011 to 44,000 in 2017 (see homepage of the Egenanställningsföretagens Branschorganisation, http:/www.egenanstallning.org/index/news. Accessed 19 June 2019), and according to the Government White Paper SOU 2017:24 (fn. 1), p. 167, 18,650 persons worked at 7 (big) umbrella companies in 2015. There were approximately 29,500 active umbrella company workers in 2018 and 32,300 during 2019, according to the Swedish Statistic Service (SCB), https:/www.scb.se/AM0103. Accessed 19 June 2020. In this book chapter the focus is not on the number of workers but on the fact that it is a phenomenon that exists and is here to stay.

4 The term service consumer is used in the same way as in the European Commission, Communication from the Commission to the European Parliament, the Council, the European Economic and Social Committee and the Committee of the Regions. A European Agenda for the Collaborative Economy, COM (2016) 356 final, of 2 
between them are conducted electronically. The Swedish umbrella companies' business model is that the umbrella company worker (to be) finds an assignment. He either bids for work on a digitalised platform or finds it in some other way. If successful, the umbrella company worker (to be) negotiates both the working conditions and the remuneration with the client. The umbrella company worker (to be) then makes sure the client has signed a contract with the umbrella company. The umbrella company worker is employed by the umbrella company on a short fixed-term employment contract for the duration of the assignment. When the work is done the client is invoiced by the umbrella company. Once the client has paid the umbrella company, the platform worker is credited his remuneration, after deductions for tax, social security contributions, and the umbrella company's commission. ${ }^{5}$

Umbrella companies are promoted as an easy way for people who do not want the administrative burden of having a company of their own, to work and concentrate on their work performance instead of on administration. Umbrella companies attract many different types of performing parties, both in the digitalised economy and in the "old" economy in traditional freelance sectors like journalism, acting etc. In Sweden, it is the employer and not the employee who pays taxes and social security contributions to the Swedish Tax Agency. Self-employed persons with a Business Tax Certificate pay themselves and the administrative burden of being selfemployed is significant compared to that of being an employee. There are, from a social security perspective, no particular reasons for using umbrella companies since e.g. the social security fees are the same for employees and self-employed persons.

Swedish umbrella companies have a trade organisation where membership is conditioned on companies taking responsibility for the performing parties during the time they are working. ${ }^{6}$ The organisation's point of view is that the performing parties are employed by the umbrella companies for the duration of their assignments and that the umbrella companies take full responsibility for their umbrella company workers. Umbrella com-

June 2016, p. 3, https:/ec.europa.eu/transparency/regdoc/rep/1/2016/EN/1-2016-35 6-EN-F1-1.PDF. Accessed 20 August 2020.

5 See Government White Paper SOU 2017:24 (fn. 1), p. 161 ff, p. 198; the Swedish Tax Agency, https://www.skatteverket.se/privat/skatter/arbeteochinkomst/inkomste r/egenanstallning. Accessed 15 June 2020; Eurofound, New Forms of Employment (fn. 1), p. 120.

6 See homepage of the Egenanställningsföretagens Branschorganisation, http://www. egenanstallning.org. Accessed 30 March 2020. 
panies of a similar construction can be found in France and Austria. ${ }^{7}$ In France and Austria the employment in itself does, however, not seem to be as important for the umbrella companies' identity as it is in Sweden. In France, portage salarial is described as a construction in between employment and self-employment. ${ }^{8}$ In contrast to the Swedish system, portage salarial in France is regulated in the statutory legislation. ${ }^{9}$ In Sweden, there is no particular regulation about umbrella companies, so it is the already existing legislation that applies to umbrella companies. In Austria, some of the umbrella companies are described as not-for-profit organisations. ${ }^{10}$ That is not a suitable description of umbrella companies in Sweden, which make up a special business model in a particular niche of the labour market. Their reason for handling administration is that they are commercial companies that make their profit by charging a percentage of the worker's income. ${ }^{11}$ Platform and other companies that do not want to employ employees need a middleman who can take on the responsibilities of the employer during assignments. This explains the demand for umbrella company services in the collaborative economy.

In Section II, I will analyse the legal prerequisites in Swedish labour legislation for the umbrella companies' business model and the concept of employment in labour law. I will then analyse the concept of employment in social security legislation, and the particular gaps and problems in the social security system and in unemployment insurance for umbrella company workers in Section III. In Section IV, the importance of supplemental social security benefits in industry-wide collective agreements are presented. In Section V, I will present conclusions. I will, for instance, analyse the umbrella companies' role as employers and in whose interest they operate. I will also analyse the business model's significance for the social security protection of umbrella company workers with the intention of determining whether or not umbrella companies are a possible way of extending

7 Eurofound, New Forms of Employment (fn. 1), pp. $118 \mathrm{ff}$.

8 Kessler, Francis, Chapter 10: New Forms of Employment in France, in: Blanpain, Roger/Hendrickx, Frank/Wass, Bernd (eds.), New Forms of Employment in Europe. Bulletin of Comparative Labour Relations Series Volume 9, Alphen aan den Rijn: Wolters Kluwer 2016, pp. $203 \mathrm{f}$.

9 Article 8 of the Law of 2008; see Kessler, Francis, Chapter 10: New Forms of Employment in France (fn. 8), p. 203 f.

10 Eurofound, New Forms of Employment (fn. 1), pp. 118 ff.

11 Frilands Finans e.g. charges 6 per cent, see homepage of Frilands Finans, https://w ww.frilansfinans.se/fragor-och-svar/. Accessed 18 July 2020. 
the social security protection to include this group of vulnerable employees and self-employed persons.

\section{Legal Prerequisites in Swedish Labour Legislation for the Umbrella Company Business Model}

\section{Basics}

The Swedish variety of umbrella companies does not exist in the other Nordic countries, in spite of the fact that these countries have seen similar developments in the collaborative economy. ${ }^{12}$ There might be several reasons for this. In this section, I will analyse the prerequisites in Swedish labour legislation that have created a demand for this particular business model and the statutory regulations that have aided its emergence.

The Swedish legislation is built on a binary system where the performing party is either employed or self-employed. The concept of employment in the 1982 Employment Protection Act is wide and covers both the concept of "workers" and that of "employees" as referred to in other countries. ${ }^{13}$ The Swedish Labour Court has not yet ${ }^{14}$ decided on any cases where they have had to determine whether umbrella company workers and platform workers are employees according to the concept of the employee in the 1982 Employment Protection Act, or whether they are selfemployed. It may very well be the case that the Labour Court will regard the relationship between the umbrella company and the umbrella company worker as one of employment with a short fixed-term contract. If the statutory act only allowed permanent full-time employment, there would be no legal prerequisites for the business model. In this respect, the 1982

12 Eurofound, New Forms of Employment (fn. 1), pp. $118 \mathrm{ff}$. and Hotvedt, Marianne Jenum/Munkholm, Natalie Videbak, Labour Law in the Future of Work, Fafo-paper 2019:06, https://www.fafo.no/pillar-vi. Accessed 20 August 2020.

13 The legislation in the United Kingdom, unlike in Sweden, separates employees from workers (cf. Section 230 (1)-(3) of the Employment Rights Act 1996) and the concept of the worker is broader and different from the concept of the employee, see Kenner, Jeff, Inverting the Flexicurity Paradigm: The United Kingdom and Zero Hours Contracts, in: Ales, Edoardo/Deinert, Olaf/Kenner, Jeff (eds.) Core and Contingent Work in the European Union: A Comparative Analysis, Oxford: Hart Publishing 2017, pp. 153-183.

14 There have been cases where the Court has had to decide whether umbrella company workers are employees in terms of the Unemployment Insurance Act, with differing results, see below. 
Employment Protection Act is flexible and allows very short employment contracts and offers generous possibilities for fixed-term employment.

\section{A Wide Concept of Employment in Labour Law ${ }^{15}$}

The employee is identified in an overall assessment of relevant criteria. ${ }^{16}$ The concept of employment is based on a core criterion: a contract by which a performing party must personally perform work on behalf of another party. ${ }^{17}$ The core criterion is so important that it must always be present. In addition to the core criterion there are other circumstances of importance to the Labour Court when they make their overall assessment of all relevant criteria. The list varies depending on the author. ${ }^{18}$ Examples of circumstances taken into account are:

15 See further Westregård, Annamaria, The Notion of "Employee" in Swedish and European Union Law: An Exercise in Harmony or Disharmony?, in: Carlson, Laura/Edström, Örjan/Nyström, Birgitta (eds.), Globalisation, Fragmentation, Labour and Employment Law: A Swedish Perspective, Uppsala: Iustus Förlag 2016, pp. 185-204; Westregård, Annamaria, Collaborative Economy: A New Challenge for the Social Partners, in: Ahlberg, Kerstin/ Herzfeld Olsson, Petra /Malmberg, Jonas (eds.), Niklas Bruun I Sverige. En vänbok, Uppsala: Iustus Förlag 2017, pp. 427-438; Westregård, Annamaria, Digital Collaborative Platforms: A Challenge for Social Partners in the Nordic Model, in: Nordic Journal of Commercial Law, 1 (2018), pp. 92 ff., https://doi.org/10.5278/ojs.njcl.v0i1.2486. Accessed 18 July 2020; Westregård, Annamaria, Key Concepts and Changing Labour Relations in Sweden, Nordic Future of Work Project 2017-2020: Working Paper 8. Pillar VI, 2019, https://www.fafo.no/pillar-vi. Accessed 20 August 2020.

16 For more about the overall assessment, see Westregard, Annamaria, The Notion of "Employee" in Swedish and European Union Law: An Exercise in Harmony or Disharmony? (fn. 15), pp. 185-204; Westregård, Annamaria, Collaborative Economy: A New Challenge for the Social Partners (fn. 15), pp. 427-438; Westregard, Annamaria, Digital Collaborative Platforms: A Challenge for Social Partners in the Nordic Model (fn. 15), pp. 92 ff.; Westregård, Annamaria, Key Concepts and Changing Labour Relations in Sweden (fn. 15).

17 Originally Adlercreutz, Axel, Arbetstagarbegreppet, Stockholm: Norstedts 1964, p. 186, 276 ff. and later Malmberg, Jonas/Bruun, Niklas, Ds. 2002:56 Hållfast arbetsrätt för ett föränderligt arbetsliv, Stockholm: Fritzes 2002, p. 111 n. 63 identified the set of relevant circumstances or criteria, all of them fundamental prerequisites (grundrekvisit).

18 Adlercreutz, Axel, Arbetstagarbegreppet (fn. 17), p. 186 and pp. 276 ff.; Malmberg, Jonas/Bruun, Niklas, Ds. 2002:56 Hållfast arbetsrätt för ett föränderligt arbetsliv (fn. 17), p. 111 n. 63; Källström, Kent/Malmberg, Jonas, Anställningsförhållandet: inledning till den individuella arbetsrätten, Uppsala: Iustus 2016, p. 26; Sigemen, Tore/Sjödin, Erik, Arbetsätten: En översikt, Alphen aan den Rijn: Wolter Kluwer 
Is the work performed under the principal's leadership and control (salaried employment) or not (self-employment)? Is the workload measured by duration (employment) rather than by specific duties (self-employment)? Does the performing party have only one principal (salaried employment) or several (self-employment)? Who owns machinery and equipment (employees use the employer's equipment and the self-employed provide their own equipment)? What are the parties' intentions? This is a criterion of special interest when it comes to umbrella companies, as the parties have signed a fixed-term employment contract for the duration of the assignment. Does someone become an employer just because the parties have concluded an employment contract as umbrella companies and umbrella company workers do? ${ }^{19}$

The intention of the umbrella company and the umbrella company worker is for the umbrella company worker to have a fixed-term employment contract for the duration of the assignment. If the Labour Court has to decide whether a relation is to be considered an employment according to the 1982 Employment Protection Act, the Court balances the different interests between the contracting parties. In labour law it is the real circumstances between the parties rather than the intention of the parties or the written contract that matters most for the overall assessment. In cases of "false self-employment" the Labour Court ignores the contract. In such cases the employment contract may instead create "false employees". An umbrella company is definitely not an ordinary employer. A self-employed person could probably perform the same assignment without the umbrella company. On the other hand, it would not be problematic for the Labour Court to follow the intention of the parties, were it beneficial for the weaker party - here the umbrella company worker. In a recent Government White Paper, umbrella company workers were recognised as employees, see Section III 3 below. ${ }^{20}$ The Swedish Labour Court has not yet had a case where they have had to decide whether umbrella company workers should be regarded as employed by the umbrella company.

2017, p. 31; Inghammar, Andreas, The Concept of "Employee": The Position in Sweden, Restatement of Labour Law, in: Waas, Bernd/van Voss, Guus Heerma (eds.), The Concept of Employee, Oxford: Hart Publishing 2017, p. 686; Lunning, Lars/Toijer, Gudmund, Anställningsskydd: En lagkommentar, 11th Edition, Alphen aan den Rijn: Wolters Kluwer 2016, p. 27.

19 Westregård, Annamaria, Key Concepts and Changing Labour Relations in Sweden (fn. 15), p. 9 ff.

20 Government White Paper SOU 2020:26, En sjukförsäkring anpassad efter individen, p. $62 \mathrm{ff}$. 
One circumstance that speaks for a wide employment concept is that it was the legislator's intention according to the travaux préparatoires that the concept of employment should, in dubious cases, be interpreted as if there was an employment in hand. ${ }^{21}$ This statement in the Bill to Parliament ${ }^{22}$ was about the concept of employment in the 1976 Co-Determination Act (1976:580), but it has been repeated by the Supreme Court according to the 1992 Pay Guarantee Act in the case of bankruptcy. ${ }^{23}$ Whether the interpretation principle is still valid for the Labour Court has been put into question and the principle has been found to probably not be valid when the concept is interpreted in social security legislation. ${ }^{24}$ As we will see in Section III below, the concept of employment is interpreted differently in social security legislation than in labour law. This can prove fatal for the umbrella company worker, who can be employed by the umbrella company for the duration of the assignment but after the assignment be regarded as self-employed according to the 1997 Unemployment Insurance Act and therefore not be entitled to unemployment benefits in the same way as other short fixed-term employees.

The employer is "the party on whose behalf the employee performs work". ${ }^{25}$ In the private sector, where the umbrella companies operate, the concept of the employer in the labour legislation is based on the principle of the legal subject. This means that the employer is the legal or physical person who concludes the employment contract. In this business model it is the umbrella company that signs the employment contract with the performing party and therefore is the employer according to this principle.

21 In Sweden, the legislation is interpreted according to the sources of the statutory acts. If the interpretation of the statutory act is unclear, the travaux préparatoires are important sources, particularly Government White Papers (SOU) and Bills to Parliament (proposition). The content of statutory acts is clarified by caselaw, and here the Labour Court's rulings are of special interest. The doctrine in the legal literature has an impact, especially the arguments about how to interpret the other sources. See Fablbeck, Reinhold/Sigeman, Tore, European Employment and Industrial Relations Glossary: Sweden, London: Sweet \& Maxwell 2001, p. $286 \mathrm{ff}$.

22 Bill to Parliament (prop. med förslag till arbetsrättsreform) 1975/76:105 bil. 1 pp. 309 and 324 and Lunning, Lars/Toijer, Gudmund, Anställningsskydd: En lagkommentar (fn. 18), p. 26.

23 Supreme Court ruling NJA 1996, p. 311.

24 Lunning, Lars/Toijer, Gudmund, Anställningsskydd: En lagkommentar (fn. 18), p. 26.

25 Section 1 (2) of the 1976 Co-Determination Act (1976:580). 


\section{No Requirement for Duration of Time}

Another prerequisite in the concept of employment that is crucial for the umbrella company business model is that the labour law concept of employment in the statutory regulation (the 1982 Employment Protection Act) does not demand any duration of time. An employment can be very short and last only a few hours or even minutes. There are restrictions in some collective agreements that prohibit very short fixed-term employment, but as there are no collective agreements at industry or local level at the moment, there are no such restrictions for umbrella companies. ${ }^{26}$

\section{Generous Possibilities for Fixed-Term Employment}

The generous possibilities in statutory regulations for fixed-term employment in Sweden are essential for the umbrella companies' business model. The business model is that umbrella company workers have short fixedterm contracts for the duration of an assignment. This is possible due to Section 5 and 5(a) of the 1982 Employment Protection Act. The legislation

26 In the recent White-Collar Employee Agreement between the white-collar trade union Unionen and Almega (the employers' organisation for the Swedish service sector), there is a special form of fixed-term employment which must exceed a minimum employment period - missing in the law - of seven days, unless the employer and the employee specifically agree on a shorter period. If this rule is abused there are restrictions. The regulations concerning automatic conversion to permanent employment are extended to a total period of three years - a year more than the law requires - in a five-year period. This regulation is particularly important as it covers the service sector where a lot of the "new" precarious forms of employment exist (Section 2.2. and 2.3. of Collective agreement between Unionen and Almega concerning tech and media companies for the period 1 May 2017 to 30 April 2020. The new regulations are in Section 2.2. and valid from 1 November 2017. See also Labour Court ruling 2015 No. 50, reinterpretation of the previous rules. The regulation is the same in all Almega's 22 collective agreements for white-collar workers).

Another example is the Restaurant Collective Agreement, which regulates employment for single days (anställning för enstaka dagar). The employee is entitled to refuse the work offered if the minimum chargeable time is three hours a day. Here, the parties have struck a balance between the employer's interest in only having staff in place when there is work to be done, and the employee's interest in having to endure no more short fixed-term employment than is necessary and in rules for minimum hours $(4 \$ 1.2$. Anställning för enstaka dagar in the collective agreement between Visita and Hotel and Restaurant, HRF for the period 1 April 2017 to 31 March 2020). 
allows a general fixed-term employment for a maximum of two years (within a frame of five years) and after that the employment is converted into a permanent employment. General fixed-term employment, in contrast to other forms of work, entails that employers can hire on a temporary basis without having to give particular reasons for why the positions are temporary. ${ }^{27}$ The statutory regulation on fixed-term employment is what distinguishes Sweden from the other Nordic countries, where legislation does not to the same extent allow fixed-term employment. This is probably a crucial element of the expansion of umbrella companies in Sweden as opposed to the other Nordic countries, as the concept of employment is similar in all Nordic countries and platform work has developed at about the same level (except, so far, in Iceland). ${ }^{28}$

Short fixed-term employment is regarded as a problem for the employees. In a Government White Paper (SOU 2019:5 Tid för trygghet) the investigating committee presented a legislative proposal with the intention of improving the conditions for employees with short fixed-term employment contracts. If an employee has more than two short fixed-term employment contracts within 30 days, the time between the employment should also be regarded as employment in accordance with the $1982 \mathrm{Em}$ ployment Protection Act and its statutory regulations about re-employment (after twelve months if the employer rehires someone within nine months) ${ }^{29}$ and conversion to permanent employment (after two years within a frame of five years). It is currently uncertain if the proposal will be turned into legislation. Nothing in particular is said about umbrella company workers. There will be application difficulties in respect to both re-employment and conversion to permanent employment owing to the umbrella companies' special business model.

\section{Umbrella Companies and Temporary Work Agencies}

Umbrella companies operate in much the same way as temporary work agencies, with one difference being that it is the employer who decides when a temporary employee works, while an umbrella company worker

27 Bill to Parliament (prop. 2006/07:111 Bättre möjligheter till tidsbegränsad anställning, m.m.), p. 32; Lunning, Lars/Toijer, Gudmund, Anställningsskydd: En lagkommentar (fn. 18), p. 251.

28 Hotvedt, Marianne Jenum/Munkholm, Natalie Videbak, Labour Law in the Future of Work (fn. 12).

29 Section 25 in the 1982 Employment Protection Act. 
decides for himself when to work and then "hires" an employer. From a labour perspective, temporary agency workers in Sweden are also employed between assignments and receive a salary. The employer provides them with work. Umbrella company workers are not employed between assignments and find their own assignments. From a social security perspective umbrella company workers will have problems entering social security between their assignments as their legal status is unclear, see Section III 3 and 4 below, while temporary agency workers, who are employees, do not encounter the same problems.

If an umbrella company is judged to be a temporary work agency, the consequence is that its employees are entitled to the basic working and employment conditions set down in the end user's collective agreements and other binding general provisions. ${ }^{30}$ The question of whether umbrella companies are covered by the 2012 Agency Work Act (2012:854) depends on the interpretation of the definition of temporary work agencies in Section 5 (1). When the statutory act was passed, umbrella companies were not mentioned in the preparatory work for the Bill to Parliament. ${ }^{31}$ At the time, the digital economy was still in its infancy and the umbrella companies were few. According to the statutory act, temporary agency work is when a company employs temporary agency workers in order to assign them work for users, under the company's supervision and direction. If a company instead places its employees to perform a particular job under its direction for another company, then that is considered contract work, which is not covered by the 2012 Agency Work Act. ${ }^{32}$ The decision whether a company should be considered a temporary work agency or not, must also correspond to the interpretation under the Temporary Agency Work Directive. ${ }^{33}$ There have not yet been any cases in the Labour Court determining whether umbrella companies should be regarded as temporary work agencies in accordance with the 2012 Agency Work Act.

30 Sections 5 (3) and 6 in the 2012 Agency Work Act (2012:854).

31 Government White Paper SOU 2011:5, Bemanningsdirektivets genomförande i Sverige; Government Bill Prop. 2011/12:178 Lag om uthyrning av arbetstagare.

32 Government White Paper SOU 2011:5 (fn. 31), p. 55; see also Labour Court ruling 2006 No. 24 on contract versus agency work.

33 Directive 2008/104/EC of the European Parliament and the Council of 19 November 2008 on Temporary Agency Work. 


\section{Umbrella Companies and the Concept of Employment according to Social Security Legislation and Unemployment Insurances}

\section{The Concept of Employment in Social Security Legislation}

The concepts of employee and employer are not defined in the same way in social security legislation as they are in labour law. There is a close connection between the concepts in social security legislation and tax law, but the concepts in labour law are different. In the social security regulations, an employee is defined as someone who has an income from employment. Income from employment or income from business is identified according to tax law. ${ }^{34}$

There is no general definition of the employer in tax and social security legislation, as it mirrors the concept of the employee. When needed, the concept of the employer is defined in statutory regulation. An example is statutory rule in the Social Security Act, which stipulates that remuneration of less than 1,000 SEK a year (1 EUR is around 10.50 SEK) is always regarded as income from employment and that the person (whether legal or natural) who pays the remuneration is regarded as an employer. ${ }^{35}$ The main reason for identifying the employer in tax and social security legislation is that according to the 2000 Social Insurance Contribution Act (2000:980) employers pay tax and social fees for their employees. The employer's responsibility for paying tax and social fees in some cases goes beyond even the concept of employment. These responsibilities also include principals that hire independent self-employed persons without a registered firm. ${ }^{36}$ Self-employed persons deemed to be owners of a business pay taxes and social fees themselves. In Sweden, there is little difference in social security expenses between hiring a self-employed person or having an employee do the work. ${ }^{37}$ The umbrella companies pay both taxes and so-

34 See e.g. Supreme Court ruling NJA 1982, p. 784. Chapter 6 Section 2 and Chapter 25 Section 10 of the 2010 Social Insurance Code (2010:110) that refers to persons who according to Chapter 13 Section 1 in the 1999 Income Tax Law are approved for a Business Tax Certificate.

35 Chapter 25 Section 7 of the 2010 Social Insurance Code.

36 Chapter 2 of the 2000 Social Insurance Contribution Act (2000:980); see also Källström, Kent, Employment and Contract Work, in: Comparative Labour Law \& Policy Journal, 21 (1999) 1, p. 162.

37 For 2020, the total mandatory employer contribution (social security fee) is 31.42 per cent of paid gross salary. It is the same for employees and for the self-employed. The employer's contribution is based on the whole income. The benefits to the individual are limited to 8 price base amounts (380,000 SEK), https://www. 
cial fees for the umbrella company workers so in this sense they are employers. This does not mean that the umbrella company worker will be regarded as an employee, since the concept of the employee does not mirror the concept of the employer (see Section III 3 and 4 below about social security and unemployment benefits for umbrella company workers).

The main reason for identifying the umbrella company workers as either employees or self-employed in social security legislation is to decide in the binary legal system which statutory regulation about access to and the calculation of benefits will apply, as there are different regulations for employees and self-employed persons. One of the most significant and important aspects of the Swedish social security system is that the self-employed are covered in a way that does not give them the exact same protection, but similar protection to that of employees. Despite the regulations creating far from exact parity, they still offer much more protection than the social security system, from which the self-employed are excluded. As we will see in the analysis in Section III 4 and 5 below, there are still gaps and problems in both the accessing and calculation of benefits. ${ }^{38}$

There are also parts of the social security system that are similar for selfemployed persons and employees. One example is occupational injury annuity and injury insurance. Anyone who works in Sweden is insured against occupational injury (illness and accidents at the workplace, while travelling to and from work, or at home if you have to stay at home because of an epidemic like the Covid-19 crisis). ${ }^{39}$ The insurance is mandatory and covers both employees and self-employed persons, which means that both are entitled to occupational injury annuity if approved by the Social Insurance Agency. The insurance against occupational injury covers the self-employed, here defined as those operating a company as a simple partnership (enskild firma), trading partnership (handelsbolag) or limited

skatteverket.se/foretagochorganisationer/arbetsgivare/arbetsgivaravgifterochskatte avdrag/arbetsgivaravgifter.4.233f91f71260075abe8800020817.html. Accessed 7 June 2020.

38 For a more general description of the Swedish social security system for employees, self-employed and precarious workers (like platform workers and others with untraditional employment contracts), see Westregård, Annamaria, Protection of Platform Workers in Sweden, Nordic Future of Work Project 2017-2020: Working Paper 12. Pillar VI. 2020, https://www.fafo.no/pillar-vi. Accessed 20 August 2020.

See also Johansson, Caroline, Autonomous Workers and Social Security - A Swedish Example, in: Revista del Ministerio de Trabajo Migraciones y Seguridad Social, 144 (2019), pp. 89-102.

39 Chapters $39-42$ in the 2010 Social Insurance Code. 
partnership (kommanditbolag), but also assignment workers (tillfälliga uppdragstagare). If the classification of some employees is unclear this can pose a problem, since they may not fit into either of the insured categories (employees and self-employed persons). The aim of the Swedish legislator is to create parity in the social security system between employees and genuinely self-employed persons, but also between different business models and company structures. This can be seen in the reforms of the last decade. In 2010 , social security and tax regulations were reformed with the express ambition of encouraging all types of work, including work performed in non-traditional forms. ${ }^{40}$ Complementary reforms were initiated or carried out in 2018 and $2019 .{ }^{41}$ The legislator also investigated the possibilities of improving the protection in the social security system with a focus on the collaborative economy and platform workers. The investigation has not resulted in any concrete suggestions of improvements since more analyses and research will be needed..$^{42}$

\section{The "Intention of the Parties" Criterion}

Within tax law, changes were made ten years ago to facilitate the start-up of small businesses, and these changes will also affect the concept of employment in social security, since this relies on the concept in tax law. An amendment called the Reinfeldt amendment was added to Chapter 13 Section 1 of the 1999 Income Tax Act. The aim was to facilitate the issuing of

40 Legislative Bill (prop. 2009/10:120).

41 A legal change in SFS 2018:670 and Legislative Bill (prop. 2017/18:168 Stärkt försäkringsskydd för studerande och företagare); proposal for legal changes in Government White Paper SOU 2018:49, F-skattesystemet - några särskilt utvalda frågor; inquiry for new legislation in Kommittédirektiv Dir. 2017:56 Trygghet och utveckling i anställning vad gäller arbetstid och ledighet; Kommittédirektiv Dir. 2018:8 En ny arbetslöshetsförsäkring för fler, grundad på inkomst; Dir 2018:26 En trygg sjukförsäkring med människan i centrum; Government White Paper SOU 2019:2, Ingen regel utan undantag - en trygg sjukförsäkring med människan i centrum. In the inquiry for legislation, Government White Paper SOU 2019:41, Företagare i de social trygghetssystemen is the intention to create more explicit regulations for calculating SGI for the genuinely self-employed operating with a company as a simple partnership (enskild firma), the qualification days in sickness insurance to create parity between different company forms, an analysis of the regulations on part-time sickness benefits and, generally, a focus on the collaborative economy and platform workers.

42 Government White Paper SOU 2019:41, Företagare i de sociala trygghetssystemen, pp. $106 \mathrm{ff}$. and 122. 
Business Tax Certificates (godkänd för F-skatt) and to thereby make it easier to start businesses with one or few principals.

The amendments to the legislation seem to be more or less a codification of existing caselaw. ${ }^{43}$ Just as before, an overall assessment is made to determine the level of independence. The difference is that now, particular criteria are emphasised and the travaux préparatoires therefore have greater importance. The intention of the parties is one example of a criterion given special weight, while the number of clients is accorded less importance. ${ }^{44}$ Other criteria mentioned in the text include the degree to which the contractor is dependent on the principal and how much he is involved in the principal's operations. The fact that the principal determines how, when and where the work is to be carried out, or that it is to be carried out on his premises and with his equipment does not, according to the preparatory works, automatically mean that the contractor is under the principal's supervision and that there is an employment at hand.

The present rules for Business Tax Certificate approval have resulted in more people being hired as sole traders, even though they are actually employed ("false" self-employed). The Ministry of Finance appointed an inquiry to look at possible alterations to the legislation..$^{45}$ In the Government White Paper (SOU 2018:49) the commissioner was particularly critical of the fact that the former employer can be the new company's only client and that the importance of the intention of the parties is given. The final Government White Paper (SOU 2019:31) however decided not to change the concept of employment but to improve and facilitate the Swedish Tax Agency's ability to follow up and ensure that those approved for a Business Tax Certificate fulfil the business criteria to avoid classification as false selfemployed in tax law (and social security legislation). ${ }^{46}$

In labour law, it is the real circumstances between the parties rather than the intention of the parties or the written contract that matter most for the overall assessment, particularly if it is a question of classifying "false self-employment". In tax law, on the other hand, the intention of the parties is a very important criterion for the overall assessment when deciding whether the performing party is self-employed or not. The intention of the parties does not seem to be of the same importance when deciding if um-

43 See Supreme Administrative Court, 2001 ref. 25 (RÅ 2001 ref. 25) and Council of Legislation's comments and Legislative Bill 2008/09:62 F-skatt åt fler, p. 25.

44 Legislative Bill 2008/09:62, pp. 25-26.

45 Dir. 2017:108 Översyn av F-skattesystemet.

46 Government White Paper SOU 2019:31, F-skattesystemet - en översyn, pp. 31 and 200. 
brella company workers will receive social security benefits. This is despite the fact that the employment concept in social security legislation is normally connected to the concept in tax law. Here again, the real circumstances seem most important, probably owing to the interest in avoiding that "false employees" receive benefits from a third party (Swedish Social Insurance Agency or unemployment insurance funds), see Section III 3 and 4 below. The result of the different approaches in different areas of legislation is that someone might well be regarded as an employee in the labour legislation but at the same time as self-employed in the social security legislation and this is exactly what can happen to umbrella company workers.

\section{Social Security for Umbrella Company Workers ${ }^{47}$}

How does the Swedish social security system function in respect to umbrella company workers? There are problems at different levels. The first problem pertains to whether the umbrella company worker is employed or self-employed according to the legislation in question. This depends on whether the umbrella company workers are regarded as employed by the umbrella company or if the relation is regarded as something else, which in the binary system means self-employed. If umbrella company workers are regarded as self-employed, they are entitled to social security benefits for the self-employed, which can be less favourable than benefits for employees. ${ }^{48}$ The second problem is that if umbrella company workers are regarded as employees according to the parties' intentions, they share the same problem in sickness insurances as other employees with irregular intermittent on-demand employment. If a person engaging in on-demand work becomes ill and does not have work scheduled, the Swedish Social Insurance Agency investigates if there is any job at all on the labour market that he or she can perform, just as they would with an unemployed person who becomes sick. This makes it more difficult for on-demand workers than for ordinary employees to receive sickness benefits. The ondemand worker also receives sickness benefits at unemployment benefits

47 Sickness and injury benefits and parental allowance benefits are regulated in the 2010 Social Insurance Code (2010:110). For further details see Westregård, Annamaria, Protection of Platform Workers in Sweden (fn. 38), pp. 25 ff.

48 Both access to and calculation of benefits for employees and self-employed are regulated in the 2010 Social Insurance Code (2010:110) see Chapters 6, 25, 27 and 28. 
level, which is lower than ordinary sickness benefits. When umbrella company workers work with an assignment and have signed a fixed-term employment contract, they are entitled to sickness benefits if they were to become ill during this period.

The legislator in Sweden has recently suggested a solution for persons with on-demand work which entails that they will receive sickness benefits for 90 days on the same conditions as other employees. ${ }^{49}$ Umbrella companies and solo self-employed persons are particularly exempted from the proposed legislation. The Government White Paper (SOU 2020:26) states that although umbrella company workers are indeed employed by the umbrella company on a general fixed-term employment, ${ }^{50}$ their fixed-term employment is limited by their assignments for other clients. If their assignments were ended by the employer they would have been included in the directive for investigation in the legislative committee (kommittédirektiv Dir. 2018:26), but they are not. It is the umbrella companies' special business model that has resulted in the exclusion of umbrella company workers from the suggested changes in the statutory regulations. The solo self-employed are excluded since they are not employed at all by the principal. ${ }^{51}$ The developments in the legislative process described above are an example of how the social security insurances are generally not adapted to the particular working conditions of umbrella company workers, who work with short assignments on an irregular basis.

\section{Unemployment Benefits for Umbrella Company Workers}

The Administrative Court of Appeal has in a few cases decided on whether umbrella company workers are entitled to unemployment benefits according to the 1997 Unemployment Insurance Act (1997:238). There are 25 unemployment insurance funds in Sweden that administrate unemployment benefits. They are regulated in the 1997 Unemployment Funds Act (1997:239). Most of them are administrated by different unions but there are also funds for the self-employed (Småa). ${ }^{52} \mathrm{~A}$ decision by the unemployment insurance fund about access to an insurance and calculation of benefits for a certain individual can be appealed to the administrative courts. It

49 Government White Paper SOU 2020:26, En sjukförsäkring anpassad efter individen, p. $62 \mathrm{ff}$.

50 According to Section 5 in the 1982 Employment Protection Act.

51 Government White Paper SOU 2020:26 (fn. 49), p. 71, reference 9.

52 See https://www.sverigesakassor.se/om-oss/in-english/. Accessed 19 June 2020. 
is of crucial importance for umbrella company workers whether they are regarded as employees or self-employed. An employee is unemployed between assignments and thus entitled to unemployment benefits. An independent contractor or a self-employed person is entitled to unemployment benefits according to the statutory regulation for the self-employed but access to unemployment benefits for the self-employed is far more complicated. If umbrella company workers are regarded as self-employed they will in most cases probably be denied unemployment benefits between assignments. ${ }^{53}$ As for unemployment insurance, the main difference between employees and the self-employed is that the self-employed have to take a hiatus in their business operations (which they can do once every fifth year) or close down the company in order to be eligible for benefits. In practice, this means that short-fixed term employees are entitled to unemployment benefits between assignments while self-employed persons are not.

Whether the umbrella company worker is regarded as an employee or self-employed depends on how the concept of employment is assessed according to the Income Tax Act (1999:1229) as the 1997 Unemployment Insurance Act (1997:238) refers to that concept of employment. ${ }^{54}$ The statutory regulation on unemployment benefits unfortunately causes problems for umbrella company workers, as they are sometimes regarded as independent contractors (even if they do not have a company of their own) and therefore as not being entitled to unemployment benefits between assignments. It is difficult to foresee whether a person will be entitled to unemployment benefits or not.

There are two legal questions here. The first concerns the role of the umbrella company as an employer and what impact that role has for the judgement, and the second concerns the question as to how the degree of independence of the umbrella company workers is to be judged. The Administrative Court of Appeal has in a few cases discussed the umbrella

53 When a self-employed individual shifts from working in his or her own company to the unemployment insurance he or she either has to close down all business activity completely or make a temporary hiatus in operations. The temporary hiatus can be made so that the company owner does not need to close down the company in order to receive unemployment insurance. If a hiatus has been made and the business activity has started again, a period of five years has to pass before the company owner can receive unemployment benefits again under a new hiatus. This regulation is therefore of no use between assignments (Section 35 in the 1997 Unemployment Insurance Act).

54 Section 34 in the 1997 Unemployment Insurance Act (1997:238) refers to Chapter 13 Section 1 in the Income Tax Act (1999:1229). 
company's role as an employer and what impact it will have for decisions on whether the umbrella company worker is an employee or not according to the 1997 Unemployment Insurance Act. ${ }^{55}$ The Court states that even if the umbrella company formally is the employer, it is implied that the employer's responsibilities will not come into force. According to the Court this, together with other operative facts, such as management, setting of wages etc., means that the umbrella companies do not have the role of an employer in the ordinary sense, and cannot from the perspective of the 1997 Unemployment Insurance Act be regarded as employers in the same way as other employers. The fact that the umbrella company acts as an administrator and contract party "between" the umbrella company worker and the client does not on its own make the umbrella company worker an employee. If other circumstances indicate that the umbrella company worker without the presence of the umbrella company would instead have been regarded as an independent contractor, then the Court can ignore that there is an employment contract between the umbrella company and the umbrella company worker. In other words, if the umbrella company worker could just as well have handled the client and the administration through a company of his own, without the umbrella company, then the umbrella company worker will be regarded as an independent contractor. He or she will then not be entitled to any unemployment benefits between assignments.

Settled caselaw from the Administrative Court of Appeal varies and the most essential criterion has been the degree of independence. ${ }^{56}$ The Administrative Court of Appeal balances different operative facts in each specific case. In one $\operatorname{case}^{57}$ the Administrative Court of Appeal stated that the operative facts that pointed in the direction of the umbrella company worker being an employee according to the 1997 Unemployment Insurance Act,

55 See e.g. Judgement of the Administrative Court of Appeal in Gothenburg of 11 May 2010 (Case No. 3059-09).

56 Judgement of the Administrative Court of Appeal in Gothenburg of 11 May 2010 (Case No. 3059-09); Judgement of the Administrative Court of Appeal in Gothenburg of 17 February 2015 (Case No. 911-15); see also the Swedish Unemployment Insurance Board (IAF) appeal to the Supreme Administrative Court in the Judgement of the Administrative Court of Appeal in Gothenburg of 11 May 2010 (Case No. 3059-09), review not granted (Case No. 4218-10). See also report from the Unemployment Insurance Board (IAF) Uppdragstagare i arbetslöshetsförsäkringen, 2016:3, pp. 15-16, about the particular difficulties relating to the solo self-employed.

57 Judgement of the Administrative Court of Appeal in Gothenburg of 17 February 2015 (Case No. 911-15). 
were that the worker was employed by the umbrella company, payed employee taxes (A-tax) and did not have a Business Tax Certificate for self-employment (F-skatt), that the umbrella company took all employers' responsibilities for him, that the client decided when and where the assignment was to be carried out and that the worker did not market his services independently but simply made his labour available. There were also operative facts that pointed in the direction of the worker being an independent contractor. The client's first contact was with the umbrella company worker and not the umbrella company and the worker used his own computer and camera. In this case the Administrative Court of Appeal decided that the umbrella company worker was not an independent contractor and was therefore entitled to unemployment benefits.

A new Unemployment Insurance Act has recently been put forward in a Government White Paper. ${ }^{58}$ Regrettably, it does not propose any solution to the problem of how to assess the degree of independence, so the problems will remain according to umbrella companies. ${ }^{59}$ One thing that might, on the other hand, ease access to unemployment benefits for umbrella company workers is that in the present legislation there is a qualifying condition requiring a person to work a specific number of hours. ${ }^{60}$ For umbrella company workers, and a lot of other non-traditional workers, it can be difficult to prove the number of hours worked. This is one possible explanation for why the unemployment benefits' degree of coverage has decreased in recent years. Out of all unemployed persons, only 40 per cent receive unemployment benefits out of a loss-of-income insurance scheme. ${ }^{61}$ It has been suggested that the minimum working hour condition be replaced with a minimum wage condition - relating to both a total income and a minimum monthly income during four months. ${ }^{62}$

The varying judgements in settled caselaw have made it difficult to foresee whether an individual umbrella company worker will be entitled to

58 The Government White Paper SOU 2020:37, Ett nytt regelverk för arbetslöshetsförsäkringen.

59 The Government White Paper SOU 2020:37 (fn. 58), p. 209 f.

60 The basic work requirements are that the person has worked at least 80 hours a month for 6 months during the last year or 480 hours in total, and at least 50 hours a month for 6 consecutive months during the last year, Section 12 in the Unemployment Insurance Act.

61 See the Homepage of Arbetslöshetsrapporten, https://arbetsloshetsrapporten.se/er sattning-akassa/. Accessed 20 August 2020.

62 The Government White Paper SOU 2020:37 (fn. 58), p. $260 \mathrm{ff}$. 
unemployment benefits or not. ${ }^{63}$ It seems important for the legislator and the courts to find "false employees", and that will have an impact on how the interests are balanced between the Swedish Social Insurance Agency or the unemployment insurance fund and the umbrella company workers.

\section{The Importance of Collective Agreements - Supplemental Benefits}

\section{The Social Parties and New Phenomena in the Labour Market}

The Nordic model relies on the regulation of the most important working conditions being arranged through collective agreements, and not via the statutory regulations. There are thus no statutory regulations on minimum wages, overtime pay, guaranteed minimum working hours, and so on.

In Sweden, there are currently no collective agreements for umbrella companies nor any industry-wide collective agreements specific to platform work. This is probably due to the fact that Swedish platform companies do not yet take on a more organised form as employers since they imply that platform workers are self-employed. ${ }^{64}$ It seems likely that those closest to collective bargaining and to concluding a collective agreement are the umbrella companies - this is despite the lack of clarity about their position as parties. The umbrella companies already have a trade organisation and claim that they are meeting their responsibilities as employers. A stumbling block in collective bargaining is the business model with short fixed-term employment. That all employees have permanent employment is one of the most important issues for the unions.

The Swedish social partners are very good at handling new situations. An example is the collective agreements for temporary work agencies - a brand new service industry in Sweden born in the early 1990s. ${ }^{65}$ Almega and LO, the blue-collar trade union, and again Almega and the white-collar trade unions, arrived at a collective agreement for staff working for

63 See report from Unemployment Insurance Board (IAF), Uppdragstagare i arbetslöshetsförsäkringen. 2016:3. p. 15 f., https:/www.iaf.se/globalassets/dokument/ra pporter/2015-2016/2016-3-uppdragstagare-i-arbetsloshetsforsakringen.pdf. Accessed 20 August 2020.

64 Westregård, Annamaria, Digital Collaborative Platforms: A Challenge for Social Partners in the Nordic Model, in: Nordic Journal of Commercial Law, 1 (2018), pp. 104 ff., https://doi.org/10.5278/ojs.njcl.v0i1.2486. Accessed 20 August 2020.

65 Eklund, Ronnie, Temporary Employment Agencies in the Nordic Countries, in: Scandinavian Studies in Law, 43 (2002), pp. 311-333. 
temporary work agencies in $2000 .{ }^{66}$ What is interesting about these two collective agreements is that they cover the entire private sector. This means that a temporary work employee can work in any of the sectors covered by the collective agreement and enjoy the same collective agreement and conditions. The exact details of the agreements differ, but the principles are the same: both cover all temporary work employees, regardless of the industry they are hired out to. Temporary work agencies and their employees are now considered to be a service industry in their own right. ${ }^{67}$ An industry-wide collective agreement for umbrella companies might have a different construction than that of the temporary work agencies, but in Sweden an industry-wide collective agreement is important in that it establishes an industry as a recognised industry. An umbrella company can conclude a collective agreement at company level.

66 The collective agreement on general employment conditions for temporary work blue-collar workers, between Temporary Work Agencies Almega (Bemanningsföretagen Almega) and the blue-collar unions Fastighetsanställdas Förbund, GSFacket för skogs, trä och grafisk bransch, Handelsanställdas förbund, Hotell och Restaurang Facket, IF Metall, SEKO-Service- och kommunikationsfacket, Svenska Byggnadsarbetareförbundet, Svenska Elektrikerförbundet, Svenska Kommunalarbetareförbundet, Svenska Livsmedelsarbetareförbundet, Svenska Musikerförbundet, Svenska Målareförbundet, Svenska Pappersindustriarbetareförbundet and Svenska Transportarbetareförbundet, for 1 May 2017 to 30 April 2020.

The collective agreement on general employment conditions for temporary work white-collar workers and professionals between Temporary Work Agencies Almega and the white-collar workers and professional unions Unionen and the Academic Alliance. The Swedish Association of Graduate Engineers is the representative for the Academic Alliance. The Academic Alliance includes a variety of professions, including university lecturers, physiotherapists, scientists, and engineers, such as Akademikerförbundet SSR, Civilekonomerna, DIK, Sveriges Arbetsterapeuter, Fysioterapeuterna, Jusek, Naturvetarna, Sveriges Farmaceuter, Sveriges Ingenjörer, Sveriges Psykologförbund, Sveriges Skolledarförbund, Sveriges Universitetslärarförbund, Sveriges Veterinärförbund, for 1 May 2017 to 30 April 2020. The collective agreement for white-collar workers and professionals has one set of conditions used throughout the temporary work industry. The blue-collar agreement has the same regulations for salary (\$4-5) and working hours $(\$ 7-9)$ in the industry where the person currently works. Other conditions such as holiday pay and insurance $(\$ 10-22)$ are the same for temporary work employees, regardless of the industry.

67 See especially the blue-collar workers' collective agreement (3) and the social partners' common declaration of intent; see also the agreement's importance for temporary work in the Government White Paper SOU 2011:5, Chapter 6.5-6. 


\section{Supplemental Collective Agreements}

The collective agreements between Sweden's major federations contain important supplemental compensation to the state social security insurance and pensions. ${ }^{68}$ All employers with a collective agreement, 92 per cent in the private sector, are obliged in the collective agreement at industry level to also keep their employees insured in accordance with the federal collective agreements. Those federal collective agreements contain sickness insurance, occupational injury insurance, supplementary industrial injury insurance, occupational life insurance, ITP-pension schemes for white-collar workers and occupational pension schemes for blue-collar workers, occupational group health insurance etc. There are also more supplemental benefits in the industry-wide collective agreements.

If a collective agreement does not cover the workplace, the employees do not get any of the benefits in the federal collective agreements. They only have the state social security insurance levels on sickness and injury benefits, parental allowance and retirement and old age benefits. ${ }^{69}$ An employer who is a not a member of any employers' association with an industry-wide collective agreement can, of course, sign up with a private insurance. ${ }^{70}$ They are normally more expensive than the federal collective agreement insurances. The collectively agreed federal social security schemes, including pensions, normally offer better and cheaper terms than other private social security schemes that are available for individual companies, due to the large number of insured persons. This is one of the reasons why, aside from regulation wages and working conditions, it is important for the umbrella company industry to conclude industry-wide collective agreements.

68 The federal level comprises the private-sector employers - the Confederation of Swedish Enterprise and Industry (Svenskt Näringsliv - SN). The union representatives are the Swedish Federation of Professional Associations (Sveriges akademikers centralorganisation - SACO) for academically qualified personnel, the Federation of White-Collar Workers (Tjänstemännens centralorganisation TCO) for white-collar workers, and the Swedish Trade Union Confederation (Landsorganisationen - LO) for blue-collar workers.

69 Westregård, Annamaria, Protection of Platform Workers in Sweden (fn. 38), pp. $27 \mathrm{f}$.

70 For more on industrial relations in Sweden, see Westregård, Annamaria, Sweden, in: Liukkunen, Ulla (eds.) Collective Bargaining in Labour Law Regimes: A Global Perspective, Springer 2019. 


\section{Conclusion}

Are umbrella companies employers and umbrella company workers employees? The intention of the parties in the employment contract is that there should be a short fixed-term employment for the duration of the assignment. The legal problem is that umbrella companies do not take on the role of an employer in the usual sense. It is the umbrella company worker and the client that have control of the assignments and over when and how the work will be carried out. The umbrella company's role is to administrate taxes, social security fees, invoice the client and pay remuneration. The umbrella company worker could however, with some administrative effort, just as well handle the situation as a self-employed worker and does not actually need the umbrella company as a middleman.

Umbrella companies have found their own niche in the labour market and are commercial enterprises that aim to make a profit. One reason why umbrella companies are anxious to take on full employer's responsibilities from a labour law perspective, is that this will further their goal of creating an industry of their own. If umbrella company workers are not employed by the umbrella companies, there will in practice be very little that separates them from ordinary accounting firms that administrate taxes and pay out salaries etc. for small solo self-employed clients with a registered firm of their own. Umbrella companies' employer responsibilities are limited to the duration of the assignment, so their burden is not particularly heavy.

In labour law the employment concept is wide, particularly in the relation between the contracting parties according to the 1982 Employment Protection Act. Nothing speaks against the fact that the Labour Court can decide on the relation between the umbrella company and the umbrella company worker as being an employment according to the intention of the parties in the employment contract. The labour legislation generally tries to prevent classification of persons as "false self-employed" workers and to reclassify them. The caselaw of the Labour Court shows that the Labour Court is more cautious about classifying anyone as self-employed. According to the principle of the legal subject, the umbrella company not the client - is the employer.

From an employment protection perspective, one problem for umbrella company workers is thus short fixed-term employment and the precariousness this creates in times of crisis, such as the Covid-19 crisis. Another problem is that the working conditions for umbrella company workers, with regard to e.g. minimum wage, overtime pay but also benefits supplemental to the Swedish social security insurances etc., have so far not been regulated in an industry-wide collective agreement. Such agreements con- 
stitute the normal way of regulating working conditions in Sweden, since working conditions are for the most part not regulated at all in statutory law, and if they are regulated, most of the labour legislation is semi-discretionary. ${ }^{71}$ At the moment it is the umbrella company workers themselves that negotiate the terms and conditions with the clients. Naturally, umbrella companies, whose commissions are normally a percentage of the workers' commissions, will not allow remuneration to be too low. Hopefully, the social parties will in a traditional Swedish way find solutions for the working conditions through an industry-wide collective agreement.

In tax law it has been a political goal to facilitate the setting up of companies for sole traders. The concept of self-employment is therefore wider there than in labour law. This will also reflect on how the concept is interpreted in social security legislation, as the concepts are linked by statutory regulations. The employer's responsibility to pay tax and social security fees covers both employees and dependent contractors. Umbrella companies therefore have to pay taxes and social security fees, regardless of whether the umbrella company workers are employees or dependent contractors (umbrella company workers do not have their own companies and do not pay tax and social security fees themselves, according to the business model). There is no legal contradiction in that an umbrella company, from a social security legislation perspective, pays taxes and social security fees for its fixed-term employees who are employees according to labour legislation, while at the same time the umbrella company workers, when it comes to social security regulations and unemployment insurance, will be regarded as self-employed persons without current assignments instead of as unemployed employees.

The concept of employment in social security legislation and with regard to unemployment benefits is more limited than in labour law. The intention of the parties in the employment contract has little impact when it comes to classification in social security legislation. If the object is to identify employees, it is more important to determine whether the income comes from an employment or from business activity, as this will determine which statutory regulations are applicable: the ones for employees or the ones for the self-employed. The aim in social security legislation seems rather to be to identify "false employees" in order to avoid that e.g. umbrella company workers are deemed entitled to benefits for employees if they are in fact independent.

71 Westregård, Annamaria, Sweden (fn. 70). 
From a social security perspective, the main problem is that umbrella company workers so easily fall between the regulations for employees and the self-employed, due to their significant level of independence. The uncertain situation for umbrella company workers - at what level their social security and unemployment benefits should be calculated or indeed if they should receive any at all - is naturally a huge disadvantage. This will also in times of crisis make them more vulnerable than other employees. The introduction of a "new" business model, like that of umbrella companies, might rather - from a social security perspective - complicate than ease the situation of the employees at the moment, since the uncertainty with regard to how those new workers should be classified has increased. It might not make a huge difference to the final decisions whether umbrella company workers are entitled to e.g. unemployment benefits. Without the umbrella companies, a large part of the umbrella company workers would probably automatically have been regarded as self-employed persons instead of as employees; at least some of them are regarded as the latter now.

The problem of access to and calculation of benefits at basic level in the social security insurance for a new business model in Sweden remains for the legislator to solve. So far, the legislator has not shown much interest in including umbrella company workers in the inquiries for new legislation to improve the statutory regulations for this vulnerable group. 
